University of Wollongong

Research Online

Faculty of Engineering and Information

Faculty of Engineering and Information

Sciences - Papers: Part A

Sciences

$1-1-2014$

Rejection and fate of trace organic compounds (TrOCs) during membrane distillation

Kaushalya Wijekoon

University of Wollongong, kcw998@uowmail.edu.au

Faisal Ibney Hai

University of Wollongong, faisal@uow.edu.au

Jinguo Kang

University of Wollongong, jkang@uow.edu.au

William E. Price

University of Wollongong,wprice@uow.edu.au

Tzahi Cath

Colorado School Of Mines

See next page for additional authors

Follow this and additional works at: https://ro.uow.edu.au/eispapers

Part of the Engineering Commons, and the Science and Technology Studies Commons

Research Online is the open access institutional repository for the University of Wollongong. For further information contact the UOW Library: research-pubs@uow.edu.au 


\title{
Rejection and fate of trace organic compounds (TrOCs) during membrane distillation
}

\begin{abstract}
In this study, we examined the feasibility of membrane distillation (MD) for removing trace organic compounds (TrOCs) during water and wastewater treatment. A set of 29 compounds was selected to represent major TrOC groups, including pharmaceuticals, steroid hormones, phytoestrogens, UV-filters, industrial chemicals, and pesticides that occur ubiquitously in municipal wastewater. Results reported here suggest that rejection and fate and transport of TrOC during MD are governed by their volatility and, to a lesser extent, hydrophobicity. All TrOCs with pKH $>9$ (which can be classified as non-volatile) were well removed by MD. Among the 29 TrOCs investigated in this study, three compounds (i.e.

4-tertoctylphenol, 4-tert-butylphenol and benzophenone) possess moderate volatility $(\mathrm{pKH}<9)$ and therefore had the lowest rejection efficiencies of 54,73 and $66 \%$, respectively. The results suggest that the rejection of TrOCs with $\mathrm{pKH}<9$ may be governed by the interplay between their hydrophobicity and volatility. In addition, the fate and transport of the TrOCs during the MD process was also investigated. Hydrophilic TrOCs having negligible volatility were concentrated in the feed, while hydrophobic compounds with moderate volatility were substantially lost due to evaporation or adsorption. When MD treatment was integrated with a thermophilic membrane bioreactor (MBR), near complete removal (> 95\%) of all 29 TrOCs investigated in this study was achieved despite their diverse physicochemical properties (i.e. hydrophobicity, persistency and volatility). The results suggest that MD could be a promising post-treatment to be used in conjunction with thermophilic MBR for TrOC removal.
\end{abstract}

\section{Keywords}

membrane, during, trocs, distillation, compounds, rejection, organic, trace, fate

\section{Disciplines}

Engineering | Science and Technology Studies

\section{Publication Details}

Wijekoon, K., Hai, F. Ibney., Kang, J., Price, W. E., Cath, T. \& Nghiem, L. D. (2014). Rejection and fate of trace organic compounds (TrOCs) during membrane distillation. Journal of Membrane Science, 453 (March), 636-642.

\section{Authors}

Kaushalya Wijekoon, Faisal Ibney Hai, Jinguo Kang, William E. Price, Tzahi Cath, and Long D. Nghiem 


\title{
Rejection and fate of trace organic compounds (TrOCs) during membrane distillation
}

\author{
Revised Manuscript Submitted to

\section{Journal of Membrane Science}

Nov 2013
Kaushalya C. Wijekoon ${ }^{\text {a }}$, Faisal I. Hai ${ }^{\text {a }}$, Jinguo Kang ${ }^{\text {b }}$, William E. Price ${ }^{b}$, Tzahi Cath $^{\mathrm{c}}$, and Long D. Nghiem ${ }^{\mathrm{a}, *}$
${ }^{a}$ Strategic Water Infrastructure Laboratory, School of Civil Mining and Environmental Engineering, University of Wollongong, Wollongong, NSW 2522, Australia
${ }^{\mathrm{b}}$ Strategic Water Infrastructure Laboratory, School of Chemistry
University of Wollongong, Wollongong, NSW 2522, Australia
${ }^{\mathrm{c}}$ Colorado School of Mines, Golden, CO, USA

* Corresponding author: Long Duc Nghiem, Email: longn@uow.edu.au; Ph +61 242214590 


\begin{abstract}
In this study, we examined the feasibility of membrane distillation (MD) for removing trace organic compounds (TrOCs) during water and wastewater treatment. A set of 29 compounds was selected to represent major TrOC groups, including pharmaceuticals, steroid hormones, phytoestrogens, UV-filters, industrial chemicals, and pesticides that occur ubiquitously in municipal wastewater. Results reported here suggest that rejection and fate and transport of TrOC during MD are governed by their volatility and, to a lesser extent, hydrophobicity. All TrOCs with $\mathrm{pK}_{\mathrm{H}}>9$ (which can be classified as non-volatile) were well removed by MD. Among the 29 TrOCs investigated in this study, three compounds (i.e. 4-tertoctylphenol, 4-tert-butylphenol and benzophenone) possess moderate volatility $\left(\mathrm{pK}_{\mathrm{H}}<9\right)$ and therefore had the lowest rejection efficiencies of 54,73 and $66 \%$, respectively. The results suggest that the rejection of TrOCs with $\mathrm{pK}_{\mathrm{H}}<9$ may be governed by the interplay between their hydrophobicity and volatility. In addition, the fate and transport of the TrOCs during the MD process was also investigated. Hydrophilic TrOCs having negligible volatility were concentrated in the feed, while hydrophobic compounds with moderate volatility were substantially lost due to evaporation or adsorption. When MD treatment was integrated with a thermophilic membrane bioreactor (MBR), near complete removal ( $>95 \%$ ) of all 29 TrOCs investigated in this study was achieved despite their diverse physicochemical properties (i.e. hydrophobicity, persistency and volatility). The results suggest that MD could be a promising post-treatment to be used in conjunction with thermophilic MBR for TrOC removal.
\end{abstract}

Keywords: Trace organic compounds (TrOCs), direct contact membrane distillation (DCMD), volatility, fate and transport, hydrophobicity/hydrophilicity. 


\section{Introduction}

Membrane distillation (MD) is a low temperature distillation process that involves the transport of water in the vapour phase from a feed solution through a microporous and hydrophobic membrane to the distillate (product) side. Direct contact membrane distillation (DCMD) is probably the most widely studied MD system configuration due to its simple operation [1-2]. In DCMD, the feed solution is maintained at a higher temperature than the distillate; thus, creating a vapour pressure difference between the feed and distillate. The membrane separates the liquid phase of the feed and distillate streams but allows water vapour to transport freely through its dry micro porous pores. In MD, the membrane material must be hydrophobic to prevent flooding of the pores by liquid feed or distillate under standard operating conditions. Because mass transfer can occur only in the gas phase, MD can offer complete rejection of all non-volatile solutes such as inorganic salts and pathogenic agents. As a result, to date, much of the effort in MD research has focused on desalination applications [2-5].

Unlike pressure driven membrane processes, due to the absence of a hydraulic pressure, MD is less susceptible to membrane fouling [3, 6]. Even when membrane fouling does occur, it is expected to be a less compacted layer and can be easily removed [3, 7-8]. The low operating temperature of MD allows for the utilization of solar thermal or low grade heat as the energy source [1-2, 9-13]. Given the advantages of high separation efficiency, low fouling propensity, and potentially low energy consumption (when low grade heat is readily available), MD can be useful for a range of applications beyond those for brackish and seawater desalination. Several studies have explored the use of MD for food processing, such as whey protein recovery in dairy processing [8], polyphenolic antioxidants from olive oil wastewater [14], and orange juice concentration [15], separation of fermentation broth [16] as well as treatment of wastewater from the textile [17] and petrochemical industries [10], and municipal water reuse [11, 18].

Despite the growing interest in using MD for treatment of a range of wastewaters, there is still a lack of understanding of the rejection mechanisms of trace organic compounds (TrOCs) by MD. These TrOCs have been frequently detected in raw sewage and biologically treated effluent at concentrations ranging from several $\mathrm{ng} / \mathrm{L}$ to several $\mu \mathrm{g} / \mathrm{L}$ [19-23]. As a result, the removal of these TrOCs from secondary treated effluent by advanced treatment processes such as 
nanofiltration (NF), reverse osmosis (RO), oxidation and activated carbon adsorption has been extensively investigated in recent years [24-28]. Nevertheless, only a few studies have been conducted to elucidate the rejection of specific organic compounds by MD. Moreover, the available studies are mostly concerned with industrial chemicals such as benzene [29] and trichloroethylene [30] at an elevated feed concentration.

Given the concerns associated with human and environmental exposure to TrOCs, it is important to elucidate their fate and transport during MD, particularly in water reuse applications. Examples of these include the investigation by Cath et al. [18] and Cartinella et al. [31] to treat urine and hygiene wastewater by MD for water reuse in long term space missions

and the novel membrane distillation membrane bioreactor (MDBR) concept proposed by Phattaranawik et al. [11] and Goh et al. [32].

In this paper, we studied the rejection of a broad range of TrOCs by MD. The potential application of MD as a post treatment for thermophilic MBR to enhance TrOC removal was also investigated. The transport and fate of TrOCs during MD treatment are discussed with respect to compound hydrophobicity and volatility (measured by the $\log D$ and the Henry's law constant, respectively). The results provide further insight with respect to TrOC rejection using MD, which is critical for the further development of this technology for wastewater reclamation applications.

\section{Materials and Methods}

\subsection{Experimental system}

The rejection of TrOCs by MD was evaluated using a hydrophobic microporous polytetrafloroethylene (PTFE) membrane (GE, Minnetonka, MN) and a laboratory-scale DCMD system [33]. According to the manufacturer, the average pore size and porosity of the MD membrane were $0.22 \mu \mathrm{m}$ and 70\%, respectively. The DCMD system (Fig. 1) comprised a membrane cell, a stainless steel feed tank, a glass distillate tank, two circulation pumps (Micropump Inc., USA), a temperature controller (Coleparmer, USA), and a heating element (Process Technology, USA). The membrane cell was made of acrylic glass, and a flow channel was engraved in each of the two acrylic glass blocks that make up the feed and permeate semi- 
cells. The length, width, and height of each channel were 145, 95, and $3 \mathrm{~mm}$, respectively. The feed solution was circulated from a stainless steel reservoir to the membrane cell and then returned back to the feed reservoir. A temperature sensor was placed immediately before the feed inlet to the membrane cell. The heating element and the temperature sensor were connected to a temperature control unit that was used to regulate the temperature of the feed solution. Another temperature sensor was installed immediately at the outlet of the distillate semi-cell. The temperature of the distillate was regulated using a chiller (AquaCooler, Australia) equipped with a stainless steel heat exchanging coil immersed directly in the distillate reservoir. Excess water was allowed to overflow from the distillate reservoir into a glass container, placed and continuously weighed on an analytical balance (Mettler Toledo, Switzerland). All pipework used in the DCMD test unit was covered with insulation foam to minimize heat loss. The feed and distillate tanks were covered with aluminium foil to minimise evaporation loss during the experiment. At the end of each experiment, the solution volume was measured again and the total volume loss was found to be less than $6 \%$.

\section{[FIGURE 1]}

One set of MD experiments was conducted using a synthetic feed solution containing approximately $5 \mu \mathrm{g} / \mathrm{L}$ of each TrOC in Milli-Q water. In another set of experiments, effluent obtained from a thermophilic MBR system (Supplementary Data Fig. S1) was used as the feed solution to evaluate the feasibility of combining MD with MBR. The MBR and MD experiments were conducted separately. The MBR system consisted of a $5 \mathrm{~L}$ glass reactor immersed in a PID control water bath (Julabo, Germany), three peristaltic pumps (Masterflex L/S, USA) for feeding, recirculation and effluent extraction, and an external ceramic membrane module (NGK, Japan). The ceramic membrane had a nominal pore size of $1 \mu \mathrm{m}$ and effective area of $0.09 \mathrm{~m}^{2}$. Further details of this MBR system are available elsewhere [34].

\subsection{Experimental protocol}

In all MD experiments, the feed and distillate temperatures were 40 and $20{ }^{\circ} \mathrm{C}$, respectively and the cross flow velocity of the feed and distillate circulation flow was $11.7 \mathrm{~cm} / \mathrm{s}$. The initial feed volume was $10 \mathrm{~L}$. The experiment was concluded once the water recovery had reached $70 \%$ at which stage the feed and distillate samples were collected for TrOC analysis. 
The duration of each MD experiment was approximately $24 \mathrm{~h}$. At the beginning of each MD experiment, 3.35 L of Milli-Q water was used as the initial distillate. Thus, TrOC concentration in the distillate was corrected for dilution by taking into account the initial volume of Milli-Q water in the distillate.

The MBR system was operated under thermophilic conditions $\left(40{ }^{\circ} \mathrm{C}\right)$ with an average dissolved oxygen (DO) concentration of $2.9 \mathrm{mg} / \mathrm{L}$, hydraulic retention time of $24 \mathrm{hr}$, and average mixed liquor $\mathrm{pH}$ of 7.7. Excess sludge was withdrawn every week to maintain the mixed liquor suspended solid (MLSS) concentration in the reactor at $5000 \mathrm{mg} / \mathrm{L}$, resulting in a solids retention time (SRT) of 140 days. The system was fed with a synthetic wastewater containing $100 \mathrm{mg} / \mathrm{L}$ glucose, $100 \mathrm{mg} / \mathrm{L}$ peptone, $17.5 \mathrm{mg} / \mathrm{L} \mathrm{KH}_{2} \mathrm{PO}_{4}, 17.5 \mathrm{mg} / \mathrm{L} \mathrm{MgSO}_{4}, 10 \mathrm{mg} / \mathrm{L} \mathrm{FeSO}$, $225 \mathrm{mg} / \mathrm{L}$ $\mathrm{CH}_{3} \mathrm{COONa}$ and $35 \mathrm{mg} / \mathrm{L}$ urea [35].

Prior to the commencement of this study, the MBR system had been acclimatized at 40 ${ }^{\circ} \mathrm{C}$ and operated for more than two months to produce constant effluent quality (Supplementary Data Fig. S2). TrOCs were introduced to the MBR feed to obtain approximately $5 \mu \mathrm{g} / \mathrm{L}$ of each compound and the MBR system was operated continuously at similar operating conditions. Then, the effluent was collected and used as MD feed. In good agreement with the previous studies [24, 36-37] no significant difference in the biological performances of the MBR was observed following the introduction of TrOC. Key operational parameters including MLSS, mixed liquor volatile suspended solid (MLVSS), DO, TOC and TN removal, and permeate turbidity were continuously monitored to ensure the biological stability of the MBR. The performance of the MBR system was stable throughout this study with respect to these parameters. TOC and TN removal were stable at 91 and $47 \%$, respectively. The turbidity of the MBR permeate was always below 0.9 NTU. The MLVSS/MLSS ratio of the sludge remained constant at approximately 0.76 throughout the experimental period. In addition, the MBR system was operated at a transmembrane pressure (TMP) below $90 \mathrm{kPa}$ (13 psig) to maintain a constant permeate flux, and no abnormal variation in TMP was observed over the entire study (Supplementary Data Fig. S3).

TrOC removal or rejection $(\mathrm{R})$ is defined as: 


$$
\mathrm{R}=100 \times\left(1-\frac{\mathrm{C}_{\mathrm{P}}}{\mathrm{C}_{\mathrm{F}}}\right)
$$

where $C_{p}$ and $C_{F}$ are concentration of the specific compound in the permeate and feed, respectively. The term rejection was used for the MD process while the term removal was used for MBR and the combined treatment of MBR and MD to take into account the fact that TrOC can also be biologically degraded. Losses of TrOCs during the MD process were calculated by considering the mass balance of each compound in the feed, concentrate and distillate as given in Equation 2.

$\mathrm{C}_{\mathrm{F}} \times \mathrm{V}_{\mathrm{F}}=\left(\mathrm{C}_{\mathrm{D}} \times \mathrm{V}_{\mathrm{D}}\right)+\left(\mathrm{C}_{\mathrm{C}} \times \mathrm{V}_{\mathrm{C}}\right)+$ total loss

In Equation 2, $\mathrm{C}_{\mathrm{F}}, \mathrm{C}_{\mathrm{D}}$ and $\mathrm{C}_{\mathrm{C}}$ are concentration in the feed, distillate and concentrate, respectively. Similarly, $V_{F}, V_{D}$ and $V_{C}$ are the volume of the feed, distillate and concentrate, respectively.

\subsection{Trace organic contaminants}

A set of 29 TrOCs was selected to represent pharmaceuticals, steroid hormones, phytoestrogens, UV-filters (i.e., active ingredients of sunscreens), industrial chemicals, and pesticides that occur ubiquitously in municipal wastewater [19-23]. Analytical grade samples of these compounds were obtained from Sigma-Aldrich (Saint Louis, MO, USA). A combined stock solution of all the TrOCs was prepared in pure methanol and kept at $-18{ }^{\circ} \mathrm{C}$ in the dark. $\log D$ values of these compounds were obtained from the SciFinder Scholar database (https://scifinder.cas.org/scifinder) at pH 9 (Table 1). Vapour pressure, molecular weight (MW), and water solubility of each selected compound were also obtained from the SciFinder Scholar database (Supplementary Data Table S1) to calculate the Henry's law constant as: H $\left(\operatorname{atm} . \mathrm{m}^{3} / \mathrm{mol}\right)=$ Vapour pressure $\times \mathrm{MW} /$ water solubility. The $\mathrm{pK}_{\mathrm{H}}$ value presented in Table 1 is defined as $\mathrm{pK}_{\mathrm{H}}=-\log _{10} \mathrm{H}$. It is important to note that because the water solubility used to calculate the Henry's law constant was obtained at $25^{\circ} \mathrm{C}$, the actual $\mathrm{pK}_{\mathrm{H}}$ values at $40{ }^{\circ} \mathrm{C}$ (which was used during the MD experiment) could deviate slightly from those values presented in the Table 1. 
The $\mathrm{pH}$ of the synthetic feed solution was 8.5 and 8.6 at the beginning and the end of the MD experiment, respectively. The initial $\mathrm{pH}$ value of the MBR effluent was 7.8 and it increased to $\mathrm{pH} 9.1$ by the end of the experiment. Accordingly, the $\log D$ and $\mathrm{pK}_{\mathrm{H}}$ values of the TrOCs investigated in this study were obtained at $\mathrm{pH} 9$ (Table 1).

[TABLE 1]

\subsection{Analytical methods}

\subsubsection{Basic water quality parameters}

Total organic carbon (TOC) and total nitrogen (TN) were analysed using a Shimadzu TOC/TN-V $V_{\text {CSH }}$ analyser (Shimadzu, Kyoto, Japan). TOC analysis was conducted in nonpurgeable organic carbon mode. Electrical conductivity and $\mathrm{pH}$ of the feed and distillate were monitored using an Orion 4 Star Plus portable pH/conductivity meter (Thermo Scientific, Waltham, MA).

\subsubsection{TrOC analysis}

TrOC concentrations were determined using an analytical method previously reported by Hai et al. [38]. This method consisted of a solid phase extraction procedure followed by gas chromatography separation and quantitative determination using a mass spectrometry detector with electron ionization. Feed and distillate samples $(500 \mathrm{~mL}$ each) were extracted using $6 \mathrm{~mL}$ $200 \mathrm{mg}$ Oasis HLB cartridge (Waters, Milford, MA, USA). First, the cartridges were preconditioned with $7 \mathrm{~mL}$ dichloromethane and methanol mixture $(1: 1 \mathrm{v} / \mathrm{v}), 7 \mathrm{~mL}$ methanol, and $7 \mathrm{~mL}$ reagent water (Milli-Q water). The samples were acidified to $\mathrm{pH} 2-3$ and loaded onto the cartridges at a flow rate of $1-5 \mathrm{~mL} / \mathrm{min}$. The cartridges were then rinsed with $20 \mathrm{~mL}$ Milli-Q water and dried in a stream of nitrogen for $30 \mathrm{~min}$. The extracted TrOCs were eluted from the cartridge using $7 \mathrm{~mL}$ of methanol followed by dichloromethane and methanol mixture $(1: 1 \mathrm{v} / \mathrm{v})$ at a flow rate of $1-5 \mathrm{~mL} / \mathrm{min}$. The eluents were subsequently evaporated using a water bath (40 ${ }^{\circ} \mathrm{C}$ ) under a gentle stream of nitrogen. The extracts were dissolved with $200 \mu \mathrm{L}$ methanol which contained $5 \mu \mathrm{g}$ bisphenol A- $\mathrm{d}_{16}$ and transferred into $1.5 \mathrm{~mL}$ vials, and then further evaporated under a gentle stream of nitrogen. Finally, the extracts were derivatized by adding $100 \mu \mathrm{L}$ of $\mathrm{N}, \mathrm{O}-\mathrm{Bis}($ trimethylsilyl)trifluoroacetamide (1\% trimethylchlorosilane) and pyridine (dried with 
$\mathrm{KOH}$ solid), then heated in a heating block $\left(60-70{ }^{\circ} \mathrm{C}\right)$ for $30 \mathrm{~min}$. The derivatives were cooled to room temperature and analysed using a Shimadzu QP5000 GC-MS (Shimadzu, Kyoto, Japan) equipped with a AOC20i autosampler and a Phenomenex Zebron ZB-5 (5\% diphenyl-95\% dimethylpolysiloxane) capillary column $\left(30 \mathrm{~m} \times 0.25 \mathrm{~mm}\right.$ ID, $\left.\mathrm{d}_{\mathrm{f}}=0.25 \mu \mathrm{m}\right)$. The detection limit of the selected compounds was in the range of 1 to $20 \mathrm{ng} / \mathrm{L}$ [38].

\section{Results and discussion}

\subsection{Basic Performance of the MD Process}

The MD experiments were analyzed considering the distillate flux, water recovery, $\mathrm{pH}$ and conductivity variation (Supplementary Data Table S1). The distillate flux was continuously monitored to assess the stability (Fig. 2). There was no notable difference in the performance of the MD process with respect to the water flux and conductivity rejection when either the synthetic solution or MBR effluent was used as the feed. Both experiments achieved satisfactory water recovery at $70 \%$. The average TOC and TN concentrations of the MBR effluent were $15 \pm$ 6 and $17 \pm 4 \mathrm{mg} / \mathrm{L}$, respectively. However, this high residual organic content in the MBR effluent did not exert any negative impact on the MD process. TOC and TN concentrations of the distillate were consistently less than $1 \mathrm{mg} / \mathrm{L}$. When either the synthetic solution or the MBR effluent was used as the feed to the MD process, the water flux was stable at approximately 17.5 $\mathrm{L} / \mathrm{m}^{2} . \mathrm{h}$ and no flux decline was observed during the entire experimental period (Fig. 2). The conductivity of the distillate was consistently below $10 \mu \mathrm{S} / \mathrm{cm}$ regardless of the salinity level in the feed (Supplementary Data Table S1).

\section{[FIGURE 2]}

\subsection{Rejection and fate of TrOCs during MD}

\subsubsection{TrOC rejection}

Most of the 29 TrOCs investigated were effectively removed by MD (Fig. 3). However, it is important to note that only a moderate rejection efficiency was observed for several compounds. In particular, 4-tert-octylphenol showed the lowest rejection (54\%). In MD, mass transfer occurs only in the gas (vapour) phase. Thus, the transport of TrOCs from the feed to the 
distillate solution depends on their volatility. Not surprisingly, all TrOCs with $\mathrm{pK}_{\mathrm{H}}$ value higher than 9 (low volatility) were well removed by the MD process. Oxybenzone is the only exception. Compared to other TrOCs, the relatively lower rejection (81\%) of oxybenzone in relation to its $\mathrm{pK}_{\mathrm{H}}$ value as plotted in Fig. 3 could be attributed to the strong dependence of its $\mathrm{pK}_{\mathrm{H}}$ value on pH. $\mathrm{pK}_{\mathrm{H}}$ values at $\mathrm{pH} 9$ have been plotted in Fig. 3. However, it is noteworthy that the $\mathrm{pK}_{\mathrm{H}}$ value of oxybenzone changes from 9.23 to 8.39 when the solution $\mathrm{pH}$ decreases from 9 to 8 (Supplementary Data Table S2). Because in this study the feed solution pH was 8.5 and 8.6 at the beginning and the end of the MD experiment, respectively, the interpolated $\mathrm{pK}_{\mathrm{H}}(8.6)$ value of oxybenzone is actually below 9. The three TrOCs with the lowest rejection (i.e., 4-tertoctylphenol, 4-tert-butylphenol and benzophenone) also have the highest volatility (or lowest $\mathrm{pK}_{\mathrm{H}}$ values) amongst the 29 TrOCs studied. Low rejection of volatile organic compounds such as benzene [29] and trichloroethylene [30] by MD have been previously reported in the literature. However, in this study, there was no obvious correlation between rejection efficiencies and $\mathrm{pK}_{\mathrm{H}}$ values for TrOCs possessing a $\mathrm{pK}_{\mathrm{H}}$ value of less than 9. The data presented in Fig. 3 suggest that in addition to volatility, other physicochemical properties such as hydrophobicity (which can be obtained from $\log D$ ) may also influence the transport of TrOCs during MD. In fact, octocrylene, which has the fourth lowest rejection value of $81 \%$, is also the most hydrophobic compound of the 29 TrOCs. In addition, in this study most of the TrOCs with $\mathrm{pK}_{\mathrm{H}}$ of less than 9 were also hydrophobic (i.e., $\log \mathrm{D}>3$ ) and their rejection efficiency varied widely from as low as 54\% (i.e., 4-tert-octylphenol) to near complete rejection. Significant adsorption of hydrophobic organics to the MD membrane has been previously reported by Zuo and Wang [39]. The results reported in Fig. 3 suggest that the rejection of TrOCs may be governed by the interplay between their volatility and hydrophobicity.

\section{[FIGURE 3]}

\subsubsection{Fate of TrOCs in the MD process}

The fate of TrOCs during the MD experiments is presented in Fig. 4. Considering each experiment as a closed system, any loss of TrOCs could be attributed to either evaporation or adsorption to the membrane. The former is governed by the volatility and the latter is governed by the hydrophobicity. Both of these physicochemical properties could be important in determining the fate of TrOCs during MD (Fig. 4). Results reported in this study reveal that the 
hydrophilic TrOCs with low volatility $\left(\mathrm{pK}_{\mathrm{H}}>9\right)$ can be concentrated in the feed. On the other hand, significant losses through either evaporation or adsorption could be observed for moderately volatile (i.e. $\mathrm{pK}_{\mathrm{H}}$ value $<9$ ) and hydrophobic (i.e. $\log D>3$ ) compounds. As a result, moderately volatile and hydrophobic compounds such as triclosan, propoxur, amitryptyline, octocrylene and 17 $\beta$-estradiol-17-acetate did not accumulate in the feed. Indeed, concentrations of all three compounds (i.e. 4-tert-octylphenol, 4-tert-butylphenol and benzophenone) with the lowest $\mathrm{pK}_{\mathrm{H}}$ in the concentrate at the end of the experiment were lower than the initial values (Supplementary Data, Table S3). In addition, the rejections of these compounds by MD were also the lowest amongst the 29 TrOCs investigated here (Fig. 4).

\section{[FIGURE 4]}

\subsection{MBR-MD system}

MD can be operated with feed temperature compatible to that in thermophilic MBR, these two processes can complement each other for an enhanced performance. TrOC concentrations in the feed and after each of these treatment steps are shown in Supplementary Data Table S4. MBR treatment effectively removed most of the 29 TrOCs investigated in this study. High removal of these compounds during MBR treatment has also been reported elsewhere [25, 36-37, 40]. However, several compounds including propoxur, atrazine, ametryn, clofibric acid, diclofenac, carbamazepine, naproxen and fenoprop were found to be persistent to MBR treatment, and their residual concentrations in the MBR effluent were relatively high. Low removal efficiencies of these compounds have also been reported in several previous studies [36, 41-42]. It is noted that the removal efficiency of these compounds under thermophilic conditions in this study were comparatively lower than that observed in our previous study under mesophilic conditions [37]. The low removal of most of the persistent compounds can be attributed to the disturbed metabolic activity generally associated with the biological treatment at elevated temperatures [38]. Nevertheless, as illustrated in Fig.5, all TrOCs including those that were resistant to MBR treatment were effectively removed by the MD process. In this study, complete or near complete (> 95\%) removal efficiency of all 29 TrOCs was achieved by the combined MBR-MD treatment.

TrOC removal by MD as a post treatment step following an MBR has not been reported in the literature. On the other hand, the use of other post treatment processes such as NF and RO 
desalination subsequent to MBR has been previously demonstrated [24-25, 43-44]. Tam et al. [43] reported near complete removal of estrogens and disinfection by-products (trihalomethanes and halo-acetic acids) by a pilot MBR/RO system. Alturki et al. [24] also demonstrated the benefits of coupling MBR treatment and NF/RO desalination for removing 40 TrOCs with a diverse range of physicochemical properties. Results reported in the current study suggest that an MBR-MD hybrid system could be as effective as an MBR-NF/RO system for removing TrOCs. In addition, high removal of TrOCs by a combination of MBR and MD treatment can be achieved regardless of the diversity of their volatility, persistency, and hydrophobicity.

The results shed light on the prospective of integrating MD with MBR for TrOC removal (e.g., MBR coupled MD (multi pass) system and MD bioreactor), and the salinity affected complexities on removal performance would be vital to investigate. However, it was not within the scope of the current study. Overall, the high water flux, excellent distillate quality and the near complete removal of TrOCs reported here suggests that MBR-MD system could be used to ensure safe water reuse.

\section{[FIGURE 5]}

\section{Conclusion}

In this study, we have investigated the rejection of 29 trace organic compounds (TrOCs) and their fate in a membrane distillation (MD) system. Results reported here suggest that rejection and fate and transport of TrOC during MD would be mainly governed by the volatility and partially governed by the hydrophobicity of the compound. All TrOCs with $\mathrm{pK}_{\mathrm{H}}>9$ (which can be classified as non-volatile) were highly removed by MD. However, three compounds (i.e., 4-tert-octylphenol, 4-tert-butylphenol and benzophenone) with $\mathrm{pK}_{\mathrm{H}}<9$ and thus classified as partially volatile showed relatively low rejection efficiencies (i.e., 54, 73 and 66\%, respectively). The results also suggest that the rejection of TrOCs with $\mathrm{pK}_{\mathrm{H}}<9$ may be governed by the interplay between their hydrophobicity and volatility. In addition, the reported results show that hydrophilic TrOCs having negligible volatility were concentrated in the feed, while hydrophobic compounds with moderate volatility were substantially lost due to evaporation or adsorption to membrane. Membrane bioreactor followed by MD treatment resulted in near complete (>95\%) 
removal of all 29 TrOCs despite their diverse physicochemical properties (i.e., hydrophobicity, persistency and volatility).

\section{Acknowledgement}

The authors would like to thank the University of Wollongong for the PhD scholarship support to Kaushalya C. Wijekoon.

\section{References}

[1] K.W. Lawson, D.R. Lloyd, Membrane distillation, Journal of Membrane Science, 124 (1997) $1-25$.

[2] E. Curcio, E. Drioli, Membrane distillation and related operations-A review, Separation \& Purification Reviews, 34 (2005) 35-86.

[3] A. Alkhudhiri, N. Darwish, N. Hilal, Treatment of saline solutions using air gap membrane distillation: experimental study, Desalination, 323 (2013) 2-7.

[4] C.R. Martinetti, A.E. Childress, T.Y. Cath, High recovery of concentrated RO brines using forward osmosis and membrane distillation, Journal of Membrane Science, 331 (2009) 31-39.

[5] T.Y. Cath, V.D. Adams, A.E. Childress, Experimental study of desalination using direct contact membrane distillation: a new approach to flux enhancement, Journal of Membrane Science, 228 (2004) 5-16.

[6] F. He, J. Gilron, H. Lee, L. Song, K.K. Sirkar, Potential for scaling by sparingly soluble salts in crossflow DCMD, Journal of Membrane Science, 311 (2008) 68-80.

[7] S. Srisurichan, R. Jiraratananon, A.G. Fane, Humic acid fouling in the membrane distillation process, Desalination, 174 (2005) 63-72.

[8] A. Hausmann, P. Sanciolo, T. Vasiljevic, M. Weeks, K. Schroën, S. Gray, M. Duke, Fouling of dairy components on hydrophobic polytetrafluoroethylene (PTFE) membranes for membrane distillation, Journal of Membrane Science, 442 (2013) 149-159.

[9] P.A. Hogan, Sudjito, A.G. Fane, G.L. Morrison, Desalination by solar heated membrane distillation in Proceedings of the Twelfth International Symposium on Desalination and Water Re-use, in, Malta, (1991), pp. 81-90.

[10] T.-H. Khaing, J. Li, Y. Li, N. Wai, F.-s. Wong, Feasibility study on petrochemical wastewater treatment and reuse using a novel submerged membrane distillation bioreactor, Separation and Purification Technology, 74 (2010) 138-143.

[11] J. Phattaranawik, A.G. Fane, A.C.S. Pasquier, W. Bing, A novel membrane bioreactor based on membrane distillation, Desalination, 223 (2008) 386-395.

[12] J.-P. Mericq, S. Laborie, C. Cabassud, Evaluation of systems coupling vacuum membrane distillation and solar energy for seawater desalination, Chemical Engineering Journal, 166 (2011) 596-606. 
[13] F. Suárez, S.W. Tyler, A.E. Childress, A theoretical study of a direct contact membrane distillation system coupled to a salt-gradient solar pond for terminal lakes reclamation, Water Research, 44 (2010) 4601-4615.

[14] A. El-Abbassi, H. Kiai, A. Hafidi, M.C. García-Payo, M. Khayet, Treatment of olive mill wastewater by membrane distillation using polytetrafluoroethylene membranes, Separation and Purification Technology, 98 (2012) 55-61.

[15] V.D. Alves, I.M. Coelhoso, Orange juice concentration by osmotic evaporation and membrane distillation: A comparative study, Journal of Food Engineering, 74 (2006) 125-133.

[16] M. Gryta, A. Markowska-Szczupak, J. Bastrzyk, W. Tomczak, The study of membrane distillation used for separation of fermenting glycerol solutions, Journal of Membrane Science, 431 (2013) 1-8.

[17] V. Calabro, E. Drioli, F. Matera, Membrane distillation in the textile wastewater treatment, Desalination, 83 (1991) 209-224.

[18] T.Y. Cath, D. Adams, A.E. Childress, Membrane contactor processes for wastewater reclamation in space: II. Combined direct osmosis, osmotic distillation, and membrane distillation for treatment of metabolic wastewater, Journal of Membrane Science, 257 (2005) 111-119.

[19] A.S. Stasinakis, G. Gatidou, Micropollutants and aquatic environment, in: J. Virkutyte, S. Varma R, V. Jegatheesan (Eds.) Treatment of micropollutants in water and wastewatr:Integrate environmental technologies series, Interantional Water Association, London, (2010), pp. 1-51.

[20] K. Kümmerer, The presence of pharmaceuticals in the environment due to human use present knowledge and future challenges, Journal of Environmental Management, 90 (2009) 2354-2366.

[21] P. Gago-Ferrero, M.S. Díaz-Cruz, D. Barceló, Occurrence of multiclass UV filters in treated sewage sludge from wastewater treatment plants, Chemosphere, 84 (2011) 1158-1165.

[22] J. Kang, W.E. Price, Occurrence of phytoestrogens in municipal wastewater and surface waters, Journal of Environmental Monitoring, 11 (2009) 1477-1483.

[23] Y.S. Liu, G.G. Ying, A. Shareef, R.S. Kookana, Occurrence and removal of benzotriazoles and ultraviolet filters in a municipal wastewater treatment plant, Environmental Pollution, 165 (2012) 225-232.

[24] A.A. Alturki, N. Tadkaew, J.A. McDonald, S.J. Khan, W.E. Price, L.D. Nghiem, Combining MBR and NF/RO membrane filtration for the removal of trace organics in indirect potable water reuse applications, Journal of Membrane Science, 365 (2010) 206-215.

[25] L.N. Nguyen, F.I. Hai, J. Kang, W.E. Price, L.D. Nghiem, Removal of trace organic contaminants by a membrane bioreactor-granular activated carbon (MBR-GAC) system, Bioresource Technology, 113 (2012) 169-173.

[26] K. Lekkerkerker-Teunissen, A.H. Knol, L.P. van Altena, C.J. Houtman, J.Q.J.C. Verberk, J.C. van Dijk, Serial ozone/peroxide/low pressure UV treatment for synergistic and effective organic micropollutant conversion, Separation and Purification Technology, 100 (2012) 22-29. 
[27] L.N. Nguyen, F.I. Hai, J. Kang, W.E. Price, L.D. Nghiem, Removal of emerging trace organic contaminants by MBR-based hybrid treatment processes, International Biodeterioration \& Biodegradation, 85 (2013) 474-482.

[28] A.R.D. Verliefde, S.G.J. Heijman, E.R. Cornelissen, G.L. Amy, B. Van der Bruggen, J.C. van Dijk, Rejection of trace organic pollutants with high pressure membranes (NF/RO), Environmental Progress, 27 (2008) 180-188.

[29] F.A. Banat, J. Simandl, Removal of benzene traces from contaminated water by vacuum membrane distillation, Chemical Engineering Science, 51 (1996) 1257-1265.

[30] S. Duan, A. Ito, A. Ohkawa, Removal of trichloroethylene from water by aeration, pervaporation and membrane distillation, Journal of Chemical Engineering of Japan, 34 (2001) 1069-1073.

[31] J.L. Cartinella, T.Y. Cath, M.T. Flynn, G.C. Miller, K.W. Hunter, A.E. Childress, Removal of natural steroid hormones from wastewater using membrane contactor processes, Environmental Science \& Technology, 40 (2006) 7381-7386.

[32] S. Goh, J. Zhang, Y. Liu, A.G. Fane, Fouling and wetting in membrane distillation (MD) and MD-bioreactor (MDBR) for wastewater reclamation, Desalination, 323 (2013) 39-47.

[33] L.D. Nghiem, T. Cath, A scaling mitigation approach during direct contact membrane distillation, Separation and Purification Technology, 80 (2011) 315-322.

[34] K.C. Wijekoon, T. Fujioka, J.A. McDonald, S.J. Khan, F.I. Hai, W.E. Price, L.D. Nghiem, Removal of N-nitrosamines by an aerobic membrane bioreactor, Bioresource Technology, 141 (2013) 41-45.

[35] A. Alturki, J. McDonald, S.J. Khan, F.I. Hai, W.E. Price, L.D. Nghiem, Performance of a novel osmotic membrane bioreactor (OMBR) system: Flux stability and removal of trace organics, Bioresource Technology, 113 (2012) 201-206.

[36] N. Tadkaew, F.I. Hai, J.A. McDonald, S.J. Khan, L.D. Nghiem, Removal of trace organics by MBR treatment: The role of molecular properties, Water Research, 45 (2011) 2439-2451.

[37] K.C. Wijekoon, F.I. Hai, J. Kang, W.E. Price, W. Guo, H.H. Ngo, L.D. Nghiem, The fate of pharmaceuticals, steroid hormones, phytoestrogens, UV-filters and pesticides during MBR treatment, Bioresource Technology, 144 (2013) 247-254.

[38] F.I. Hai, K. Tessmer, L.N. Nguyen, J. Kang, W.E. Price, L.D. Nghiem, Removal of micropollutants by membrane bioreactor under temperature variation, Journal of Membrane Science, 383 (2011) 144-151.

[39] G. Zuo, R. Wang, Novel membrane surface modification to enhance anti-oil fouling property for membrane distillation application, Journal of Membrane Science, 447 (2013) 26-35.

[40] V. Boonyaroj, C. Chiemchaisri, W. Chiemchaisri, S. Theepharaksapan, K. Yamamoto, Toxic organic micro-pollutants removal mechanisms in long-term operated membrane bioreactor treating municipal solid waste leachate, Bioresource Technology, 113 (2012) 174-180.

[41] H. Bouju, G. Buttiglieri, F. Malpei, Perspectives of persistent organic pollutants (POPS) removal in an MBR pilot plant, Desalination, 224 (2008) 1-6. 
[42] J. Radjenović, M. Petrović, D. Barceló, Fate and distribution of pharmaceuticals in wastewater and sewage sludge of the conventional activated sludge (CAS) and advanced membrane bioreactor (MBR) treatment, Water Research, 43 (2009) 831-841.

[43] L.S. Tam, T.W. Tang, G.N. Lau, K.R. Sharma, G.H. Chen, A pilot study for wastewater reclamation and reuse with MBR/RO and MF/RO systems, Desalination, 202 (2007) 106-113.

[44] M. Jacob, C. Guigui, C. Cabassud, H. Darras, G. Lavison, L. Moulin, Performances of RO and NF processes for wastewater reuse: Tertiary treatment after a conventional activated sludge or a membrane bioreactor, Desalination, 250 (2010) 833-839. 


\title{
Rejection and fate of trace organic compounds (TrOCs) during membrane distillation
}

\author{
Supplementary Data \\ Journal of Membrane Science
}

\author{
Nov 2013 \\ Kaushalya C. Wijekoon ${ }^{a}$, Faisal I. Hai ${ }^{a}$, Jinguo Kang ${ }^{b}$, William E. Price ${ }^{b}$, Tzahi Cath $^{c}$ and \\ Long D. Nghiem ${ }^{\mathrm{a}, *}$ \\ ${ }^{a}$ Strategic Water Infrastructure Laboratory, School of Civil Mining and Environmental \\ Engineering, University of Wollongong, Wollongong, NSW 2522, Australia \\ ${ }^{\mathrm{b}}$ Strategic Water Infrastructure Laboratory, School of Chemistry \\ University of Wollongong, Wollongong, NSW 2522, Australia \\ ${ }^{\mathrm{c}}$ Colorado School of Mines, Golden, CO, USA
}

\footnotetext{
* Corresponding author: Long Duc Nghiem, Email: longn@uow.edu.au; Ph +61 242214590
} 
Table S1: MD and MBR-MD experimental conditions.

\begin{tabular}{|c|l|c|c|}
\hline \multirow{2}{*}{ Parameter } & \multicolumn{1}{|c|}{ Phase } & $\begin{array}{c}\text { MD Experiment } \\
\text { with Milli-Q as feed }\end{array}$ & $\begin{array}{c}\text { MD experiment with } \\
\text { MBR permeate as feed }\end{array}$ \\
\hline \multirow{3}{*}{$\mathrm{pH}$} & MD feed & 8.5 & 7.8 \\
\cline { 2 - 4 } & MD concentrate & 8.6 & 9.1 \\
\cline { 2 - 4 } & Initial distillate & 7.3 & 7.3 \\
\cline { 2 - 4 } & Final distillate & 7.7 & 3.6 \\
\hline \multirow{3}{*}{$\begin{array}{c}\text { Conductivity } \\
(\mu \mathrm{S} / \mathrm{cm})\end{array}$} & MD feed & $18 \pm 0.3$ & $1026 \pm 46$ \\
\cline { 2 - 4 } & MD concentrate & $130 \pm 17$ & $1.3 \pm 0.2$ \\
\cline { 2 - 4 } & Initial distillate & $1.1 \pm 0.1$ & $9.3 \pm 0.1$ \\
\cline { 2 - 4 } & Final distillate & $6.9 \pm 0.4$ & $322 \pm 2.0$ \\
\hline
\end{tabular}

Note: 1. Volume loss due to evaporation remained less than $1 \mathrm{~L}$ in each test.

2. The error was calculated from duplicate experiments.

Table S2: $\mathrm{pK}_{\mathrm{H}}$ of oxybenzone at different $\mathrm{pH}$ values.

\begin{tabular}{|c|c|c|c|r|}
\hline $\mathbf{p H}$ & Log $\mathbf{D}$ & $\begin{array}{c}\text { Water Solubility at } \\
\mathbf{2 5}^{\mathbf{0}} \mathbf{C} \text { and } \mathbf{~ p H ~ 8 ~ ( m g / L ) ~}\end{array}$ & $\begin{array}{c}\text { Vapour Pressure } \\
\text { at } \mathbf{2 5}^{\mathbf{0}} \mathbf{C} \mathbf{( m m H g )}\end{array}$ & $\mathbf{p K}_{\mathbf{H}}$ \\
\hline $\mathrm{pH} 8$ & 3.42 & 390 & $5.26 \times 10^{-6}$ & 8.39 \\
\hline $\mathrm{pH} 9$ & 2.55 & 2700 & $5.26 \times 10^{-6}$ & 9.23 \\
\hline
\end{tabular}


Table S3: Aqueous phase concentration of the selected TrOCs when tested in synthetic feed solution (in Milli-Q water).

\begin{tabular}{|c|c|c|c|c|c|c|c|c|}
\hline \multirow{2}{*}{ Compound } & \multirow{2}{*}{$\begin{array}{c}\mathrm{pK}_{\mathrm{H}} \text { at } \\
\text { pH } 9\end{array}$} & \multirow{2}{*}{$\begin{array}{c}\log D \text { at } \\
\text { pH } 9\end{array}$} & \multicolumn{2}{|c|}{ Feed (ng/L) } & \multicolumn{2}{|c|}{ Concentrate (ng/L) } & \multicolumn{2}{|c|}{ Distillate (ng/L) } \\
\hline & & & Mean & Error ( \pm ) & Mean & Error ( \pm ) & Mean & Error $( \pm)$ \\
\hline 4-tert-Octylphenol & 5.06 & 5.18 & 2292 & 828 & 585 & 110 & 631 & 109 \\
\hline 4-tert-Butylphenol & 5.15 & 3.37 & 1881 & 0 & 350 & 147 & 245 & 58 \\
\hline Benzophenone & 5.88 & 3.21 & 666 & 0 & 274 & 26 & 128 & 44 \\
\hline Propoxur & 6.28 & 1.54 & 1653 & 261 & 81 & 92 & 7 & 5 \\
\hline Atrazine & 7.28 & 2.64 & 2462 & 89 & 10722 & 387 & 57 & 16 \\
\hline Pentachlorophenol & 7.59 & 1.99 & 2924 & 459 & 8223 & 253 & 53 & 17 \\
\hline Amitriptyline & 8.18 & 4.01 & 2465 & 455 & 1569 & 105 & 217 & 84 \\
\hline Ametryn & 8.43 & 2.97 & 3133 & 117 & 10643 & 420 & 100 & 31 \\
\hline Octocrylene & 8.47 & 6.89 & 888 & 229 & 371 & 76 & 95 & 49 \\
\hline Bisphenol A & 8.66 & 3.62 & 3077 & 60 & 9070 & 266 & 283 & 56 \\
\hline $17 \beta$-Estrodiol- 17 - acetate & 8.67 & 5.11 & 3097 & 202 & 1192 & 278 & 76 & 62 \\
\hline $17 \beta-$ Estradiol & 8.93 & 4.12 & 3557 & 20 & 6944 & 603 & 38 & 24 \\
\hline Estrone & 9.03 & 3.6 & 4163 & 34 & 9231 & 271 & 140 & 79 \\
\hline Carbamazapine & 9.09 & 1.89 & 1806 & 105 & 6053 & 463 & 57 & 20 \\
\hline Oxybenzone & 9.23 & 2.55 & 3531 & 333 & 2877 & 519 & 638 & 41 \\
\hline $17 \alpha-$ Ethinylestradiol & 9.43 & 4.08 & 3276 & 145 & 4468 & 389 & 55 & 28 \\
\hline Clofibric acid & 9.54 & -1.32 & 3539 & 115 & 11594 & 72 & 22 & 14 \\
\hline Ibuprofen & 10.39 & -0.19 & 3555 & 288 & 13669 & 50 & 12 & 12 \\
\hline Estriol & 10.80 & 2.5 & 3124 & 389 & 6866 & 1172 & 16 & 16 \\
\hline Fenoprop & 11.48 & -0.29 & 2330 & 42 & 7873 & 272 & 63 & 45 \\
\hline Diclofenac & 11.51 & 0.83 & 3527 & 168 & 11633 & 414 & 123 & 132 \\
\hline Metronidazole & 11.68 & -0.14 & 742 & 156 & 3448 & 486 & 103 & 146 \\
\hline Gemifibrozil & 12.11 & 0.67 & 3941 & 82 & 13514 & 191 & 34 & 16 \\
\hline Naproxen & 12.68 & -0.73 & 3794 & 199 & 13581 & 500 & 6 & 3 \\
\hline Formononetin & 13.22 & 0.88 & 1432 & 297 & 5534 & 285 & 7 & 1 \\
\hline Ketoprofen & 13.70 & -0.84 & 3268 & 141 & 11493 & 180 & 24 & 2 \\
\hline Primidone & 13.93 & 0.83 & 1698 & 121 & 7280 & 88 & 5 & 4 \\
\hline Enterolactone & 15.19 & 1.89 & 1213 & 274 & 3076 & 933 & 2 & 2 \\
\hline
\end{tabular}

Note: Error represents the standard deviation from four measurements (duplicate samples from two replicate experiments). MD was carried out at the feed and distillate temperatures of 40 and $20^{\circ} \mathrm{C}$, respectively. The feed and distillate circulation flow rate was $2 \mathrm{~L} / \mathrm{min}$ (corresponding to $11.7 \mathrm{~cm} / \mathrm{s}$ ). 
Table S4: Aqueous phase concentration of the selected TrOCs during the MBR-MD experiments with MBR permeate as the MD feed.

\begin{tabular}{|c|c|c|c|c|c|c|c|c|c|c|}
\hline \multirow[t]{2}{*}{ Compound } & \multirow{2}{*}{$\begin{array}{c}\mathrm{pK}_{\mathrm{H}} \text { at } \\
\text { pH } 9\end{array}$} & \multirow{2}{*}{$\begin{array}{c}\log D \text { at } \\
\text { pH } 9\end{array}$} & \multicolumn{2}{|c|}{ MBR feed (ng/L) } & \multicolumn{2}{|c|}{$\begin{array}{l}\text { MBR Permeate (MD } \\
\text { feed) (ng/L) }\end{array}$} & \multicolumn{2}{|c|}{$\begin{array}{l}\text { MD Concentrate } \\
\text { (ng/L) }\end{array}$} & \multicolumn{2}{|c|}{ Distillate (ng/L) } \\
\hline & & & Mean & Error $( \pm)$ & Mean & Error ( \pm ) & Mean & Error $( \pm)$ & Mean & Error $( \pm)$ \\
\hline 4-tert-Octylphenol & 5.06 & 5.18 & 4683 & 9 & 147 & 11 & 278 & 69 & 96 & 65 \\
\hline 4-tert-Butylphenol & 5.15 & 3.37 & 4240 & 45 & 112 & 19 & 116 & 30 & 51 & 23 \\
\hline Benzophenone & 5.88 & 3.21 & 1568 & 166 & 205 & 35 & 78 & 25 & 37 & 41 \\
\hline Triclosan & 6.19 & 4.12 & 4496 & 29 & 114 & 17 & 155 & 17 & 26 & 1 \\
\hline Propoxur & 6.28 & 1.54 & 4445 & 68 & 3011 & 278 & 164 & 53 & 39 & 14 \\
\hline Atrazine & 7.28 & 2.64 & 2800 & 107 & 3215 & 98 & 10034 & 1142 & 28 & 10 \\
\hline Pentachlorophenol & 7.59 & 1.99 & 4588 & 150 & 441 & 70 & 1039 & 254 & 13 & 16 \\
\hline Amitriptyline & 8.18 & 4.01 & 4143 & 484 & 149 & 42 & 40 & 3 & 36 & 30 \\
\hline Ametryn & 8.43 & 2.97 & 4032 & 24 & 1655 & 121 & 4639 & 410 & 25 & 6 \\
\hline Octocrylene & 8.47 & 6.89 & 1231 & 235 & 31 & 21 & 50 & 18 & 33 & 14 \\
\hline Bisphenol A & 8.66 & 3.62 & 4919 & 854 & 56 & 1 & 756 & 17 & 178 & 13 \\
\hline $17 \beta$ - Estrodiol- 17- acetate & 8.67 & 5.11 & 3956 & 45 & 12 & 6 & 27 & 27 & 27 & 20 \\
\hline $17 \beta-$ Estradiol & 8.93 & 4.12 & 4359 & 22 & 5 & 5 & 0 & 0 & 0 & 0 \\
\hline Estrone & 9.03 & 3.6 & 4654 & 26 & 31 & 2 & 40 & 5 & 21 & 17 \\
\hline Carbamazapine & 9.09 & 1.89 & 3332 & 142 & 2093 & 93 & 8022 & 1332 & 32 & 12 \\
\hline Oxybenzone & 9.23 & 2.55 & 5043 & 8 & 56 & 4 & 31 & 31 & 8 & 5 \\
\hline $17 \alpha-$ Ethinylestradiol & 9.43 & 4.08 & 4131 & 339 & 236 & 22 & 125 & 91 & 80 & 11 \\
\hline Clofibric acid & 9.54 & -1.32 & 4230 & 63 & 2448 & 156 & 7245 & 1092 & 7 & 2 \\
\hline Ibuprofen & 10.39 & -0.19 & 4915 & 191 & 57 & 16 & 131 & 24 & 5 & 6 \\
\hline Estriol & 10.8 & 2.5 & 3680 & 387 & 88 & 22 & 22 & 22 & 16 & 17 \\
\hline Fenoprop & 11.48 & -0.29 & 3940 & 202 & 2071 & 108 & 5203 & 600 & 25 & 18 \\
\hline Diclofenac & 11.51 & 0.83 & 3258 & 39 & 3916 & 49 & 9993 & 645 & 19 & 5 \\
\hline Metronidazole & 11.68 & -0.14 & 851 & 86 & 127 & 2 & 282 & 86 & 5 & 5 \\
\hline Gemifibrozil & 12.11 & 0.67 & 4628 & 17 & 456 & 29 & 1473 & 183 & 6 & 1 \\
\hline Naproxen & 12.68 & -0.73 & 4746 & 196 & 2292 & 133 & 6749 & 296 & 2 & 2 \\
\hline Formononetin & 13.22 & 0.88 & 1081 & 727 & 35 & 10 & 61 & 34 & 27 & 4 \\
\hline Ketoprofen & 13.7 & -0.84 & 4452 & 107 & 273 & 29 & 757 & 41 & 23 & 6 \\
\hline Primidone & 13.93 & 0.83 & 2627 & 181 & 14 & 4 & 82 & 41 & 2 & 2 \\
\hline Enterolactone & 15.19 & 1.89 & 5530 & 29 & 241 & 78 & 23 & 16 & 114 & 49 \\
\hline
\end{tabular}

Note: Error represents the standard deviation from four measurements (duplicate samples from two replicate experiments). 


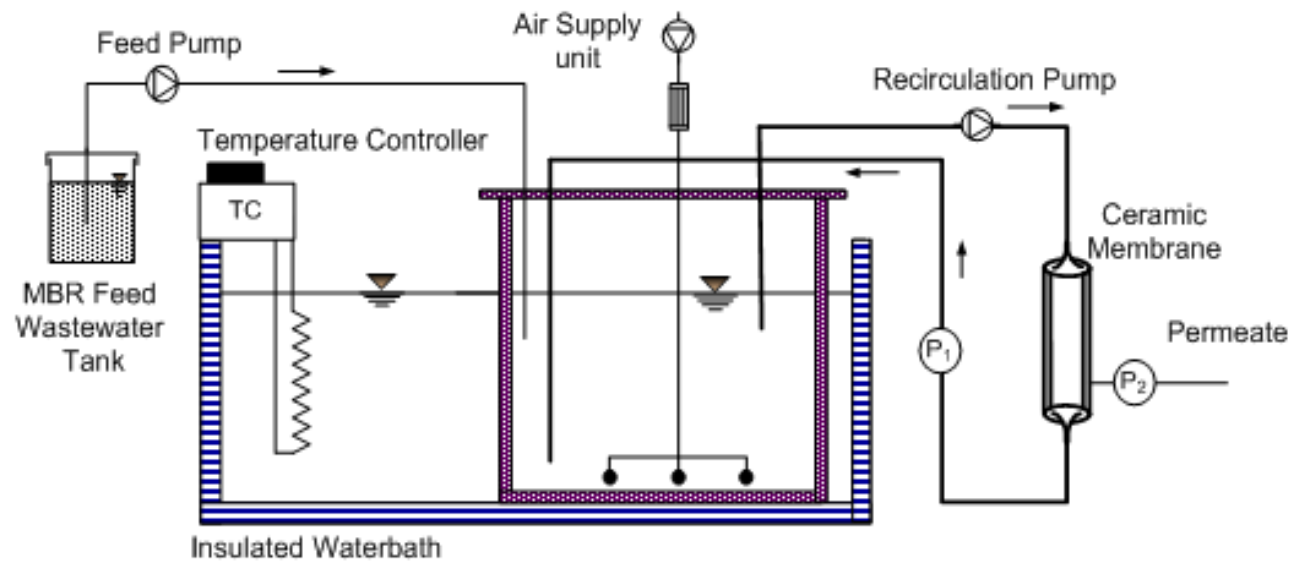

Figure S1: Schematic diagram of the MBR system. 


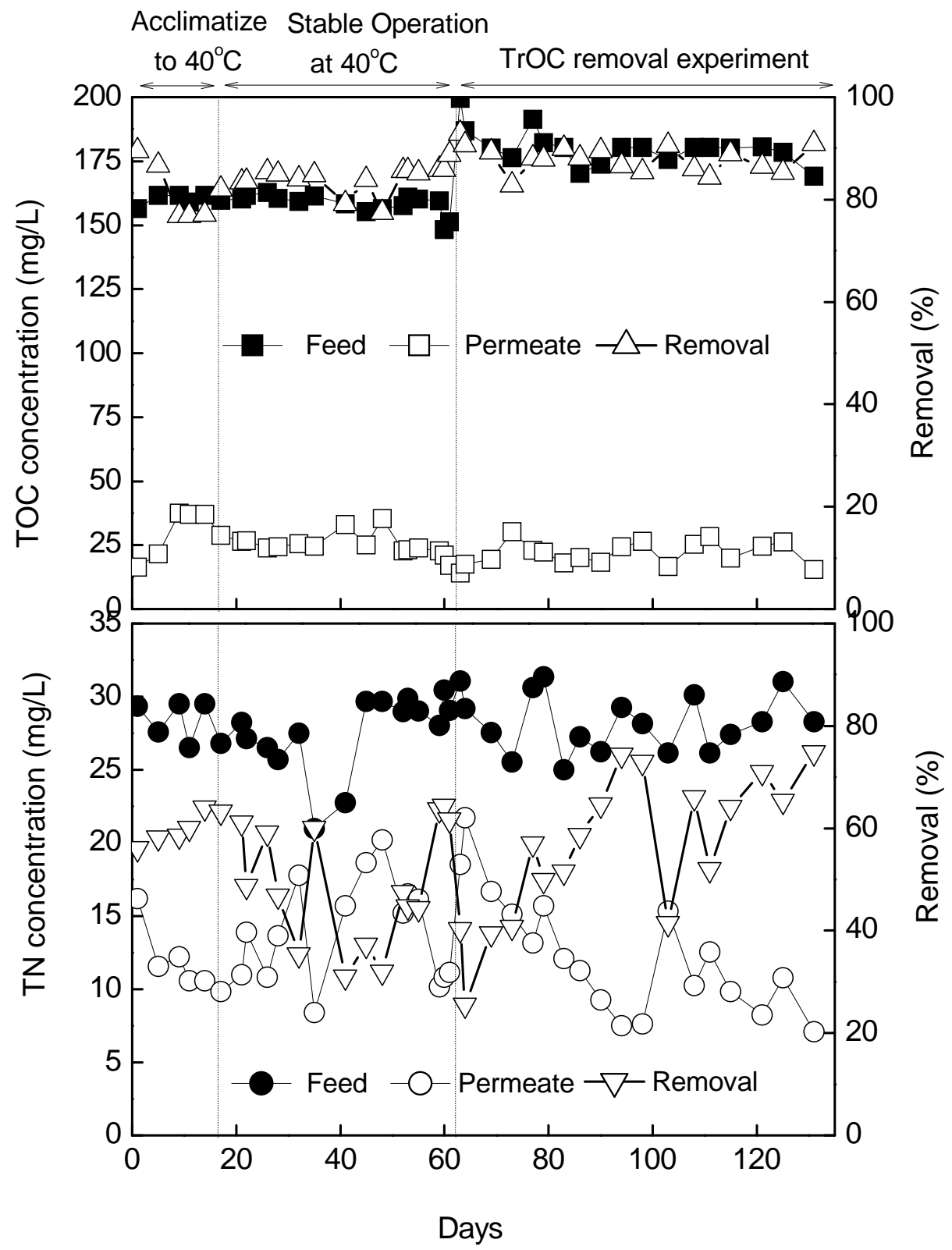

Figure S2: Variation of TOC and TN removal of MBR during acclimatization to thermophilic condition $\left(40{ }^{\circ} \mathrm{C}\right)$ and stable operation at $40{ }^{\circ} \mathrm{C}$. Operated HRT, permeate flux, mixed liquor DO concentration and $\mathrm{pH}$ were $24 \mathrm{~h}, 2.36 \mathrm{~L} / \mathrm{m}^{2} . \mathrm{h}, 2.89 \mathrm{mg} / \mathrm{L}$ and 7.68 , respectively. 


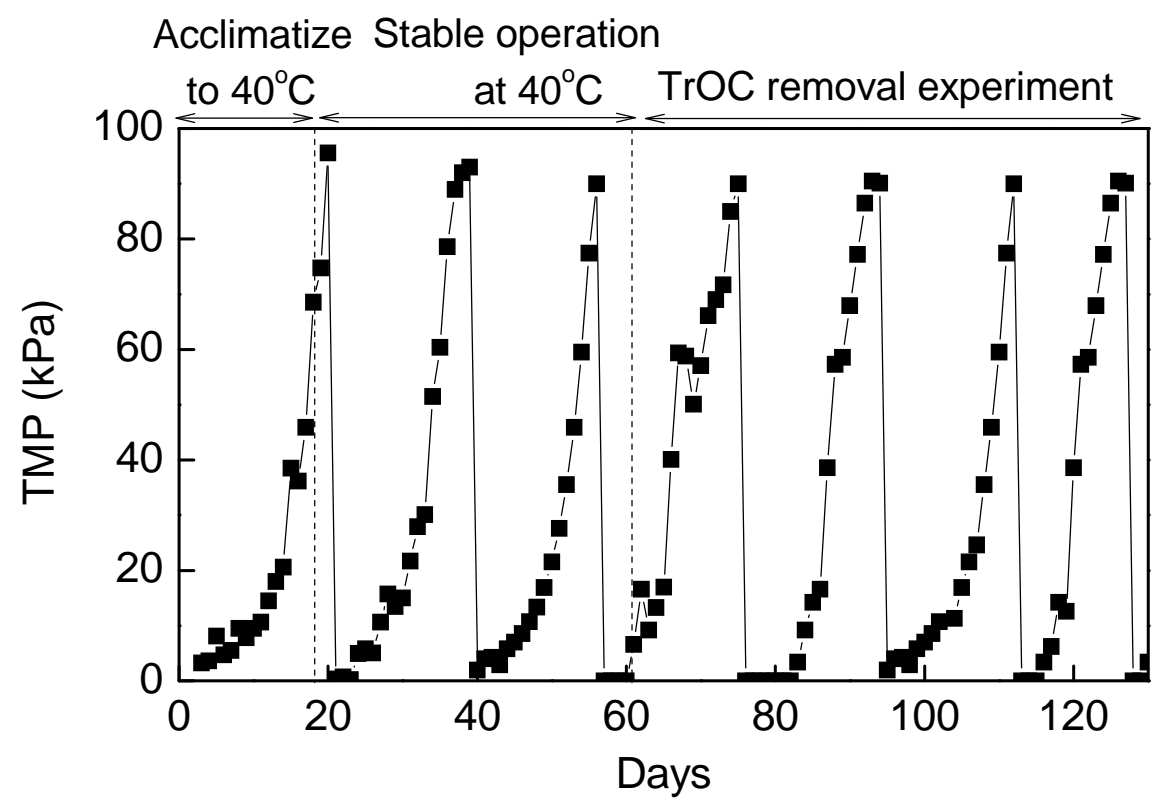

Figure S3: TMP profile of the MBR during acclimatization to thermophilic condition $\left(40{ }^{\circ} \mathrm{C}\right)$ and stable operation at $40{ }^{\circ} \mathrm{C}$. HRT and permeate flux were $24 \mathrm{~h}$ and $2.36 \mathrm{~L} / \mathrm{m}^{2}$.h (equivalent to $5 \mathrm{~L} / \mathrm{d}$ ), respectively. 


\section{LIST OF FIGURE CAPTIONS}

2 Figure 1: Schematic diagram of the DCMD system.

3 Figure 2: Permeate flux variation of $\mathrm{MD}$ and $\mathrm{MBR}-\mathrm{MD}$ experiments: MD was carried out at 4 feed and distillate temperatures of 40 and $20{ }^{\circ} \mathrm{C}$, respectively; and feed and distillate 5 circulation flow rate of $2 \mathrm{~L} / \mathrm{min}$ (corresponding to $11.7 \mathrm{~cm} / \mathrm{s}$ ).

6 Figure 3: Rejection of the 29 TrOCs by DCMD and their $\log D$ and $\mathrm{pK}_{\mathrm{H}}$ values. $\log D$ and $7 \mathrm{pK}_{\mathrm{H}}$ illustrate the values at the $\mathrm{pH}$ 9. Error bars represent the standard deviation from four 8 replicate measurements. Synthetic solution containing approximately $5 \mu \mathrm{g} / \mathrm{L}$ of each TrOC in 9 Milli-Q water was used as the feed. The MD was carried out at the feed and distillate 10 temperatures of 40 and $20^{\circ} \mathrm{C}$, respectively. The feed and distillate circulation flow rate was 2 $11 \mathrm{~L} / \mathrm{min}$ (corresponding to $11.7 \mathrm{~cm} / \mathrm{s}$ ).

12 Figure 4: The fate of the 29 TrOCs in the DCMD process with their $\log D$ and $\mathrm{pK}_{\mathrm{H}}$ values. $13 \log D$ and $\mathrm{pK}_{\mathrm{H}}$ illustrate the values at the $\mathrm{pH}$ 9. Synthetic solution containing approximately $145 \mu \mathrm{g} / \mathrm{L}$ of each TrOC in Milli-Q water was used as the feed. The fate of each compound was 15 analyzed by mass balance considering the total input, mass in concentrate and permeate, and 16 loss due to evaporation or adsorption. Calculation of the fate of TrOCs during the MD

17 process was based on the average value of four measurements (duplicate samples from two 18 replicate experiments).

19 Figure 5: Removal of TrOCs by the thermophilic MBR and by the MBR-MD as well as their $20 \log D$ and $\mathrm{pK}_{\mathrm{H}}$ values. $\log D$ and $\mathrm{pK}_{\mathrm{H}}$ illustrate the values at the $\mathrm{pH}$ 9. MBR permeate was 21 used as the feed for MD. Error bars represent the standard deviation from two replicate 22 experiments. 


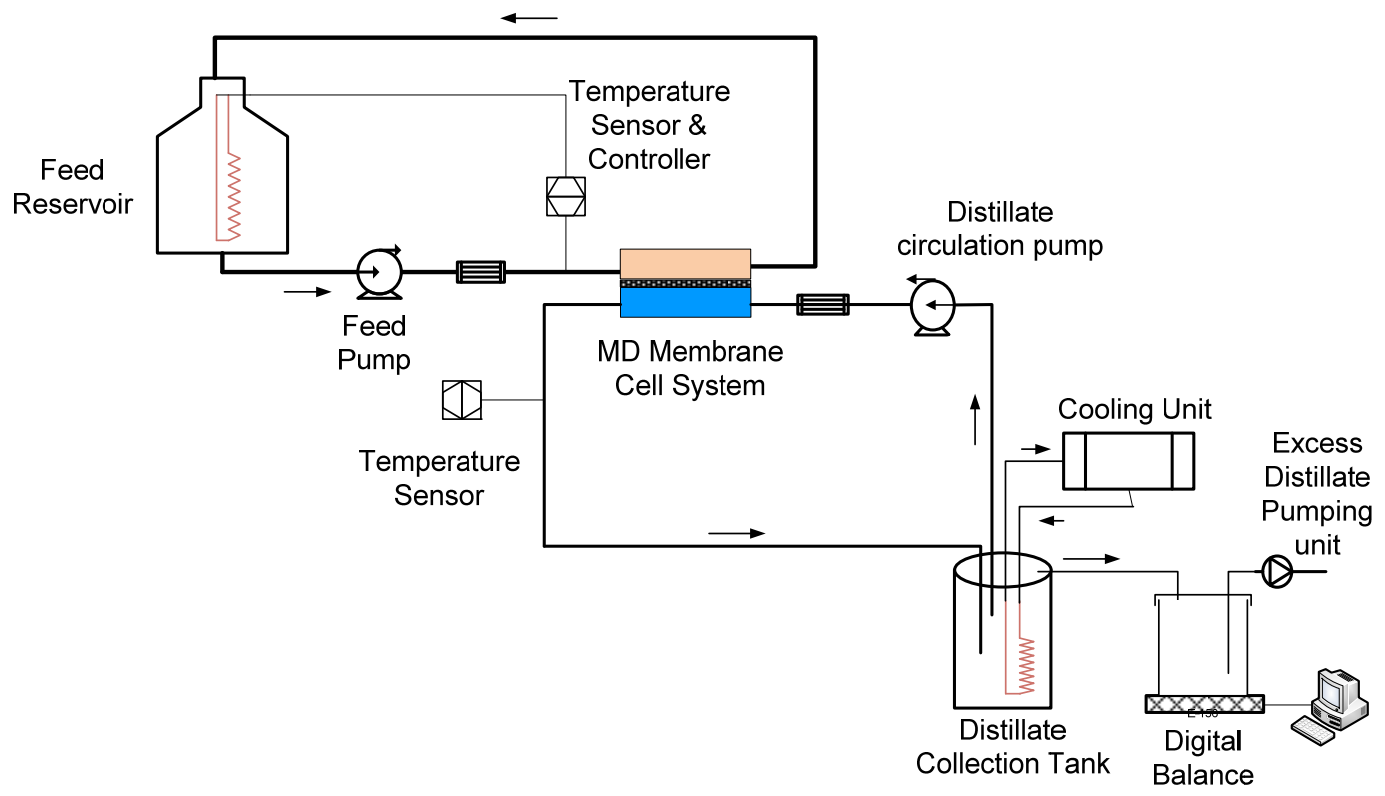

2 Figure 1 


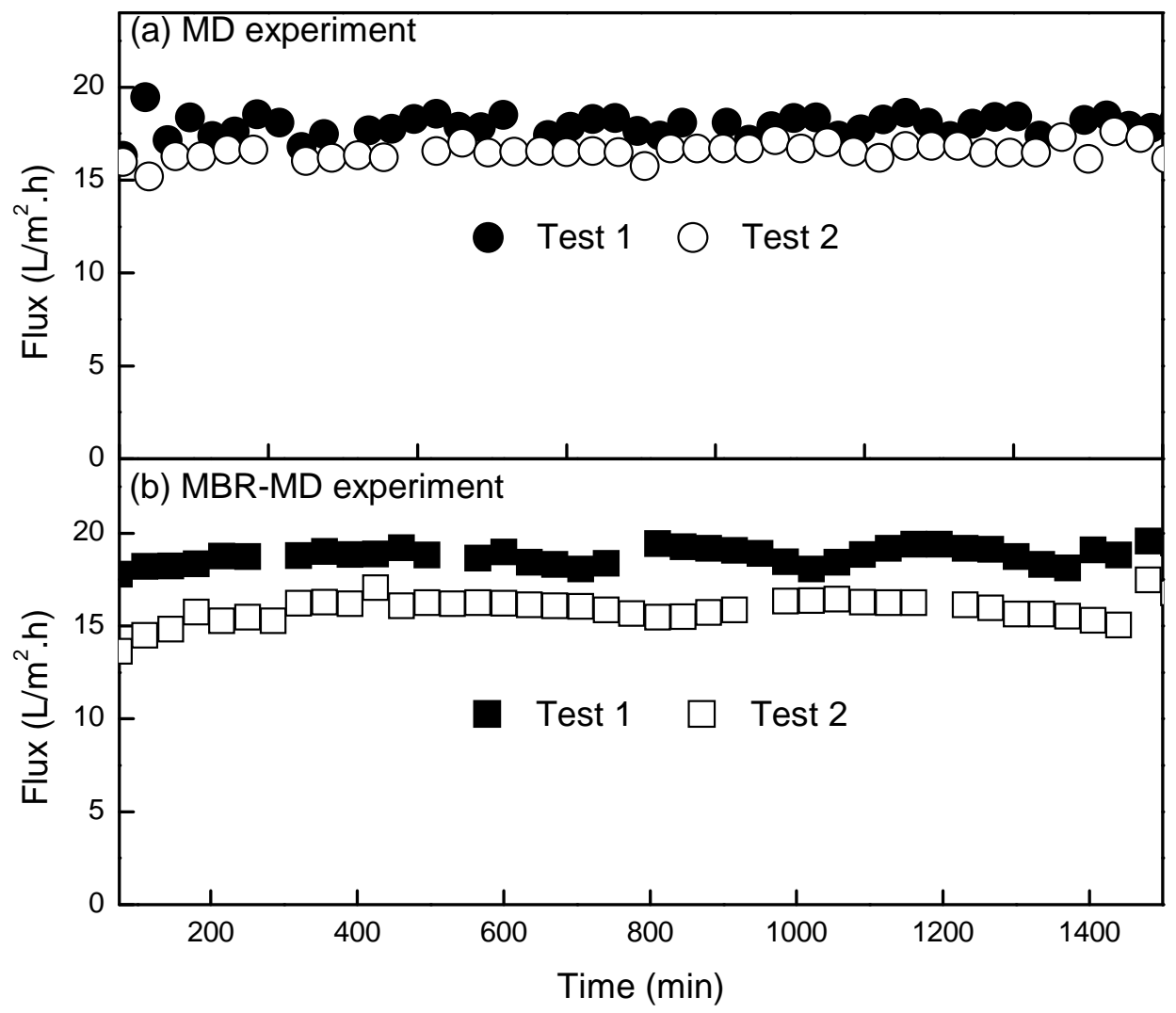

1

2 Figure 2 
$\square$ Average removal $\bigcirc \quad \mathrm{pK}_{\mathrm{H}} \mathbf{\square} \log D$

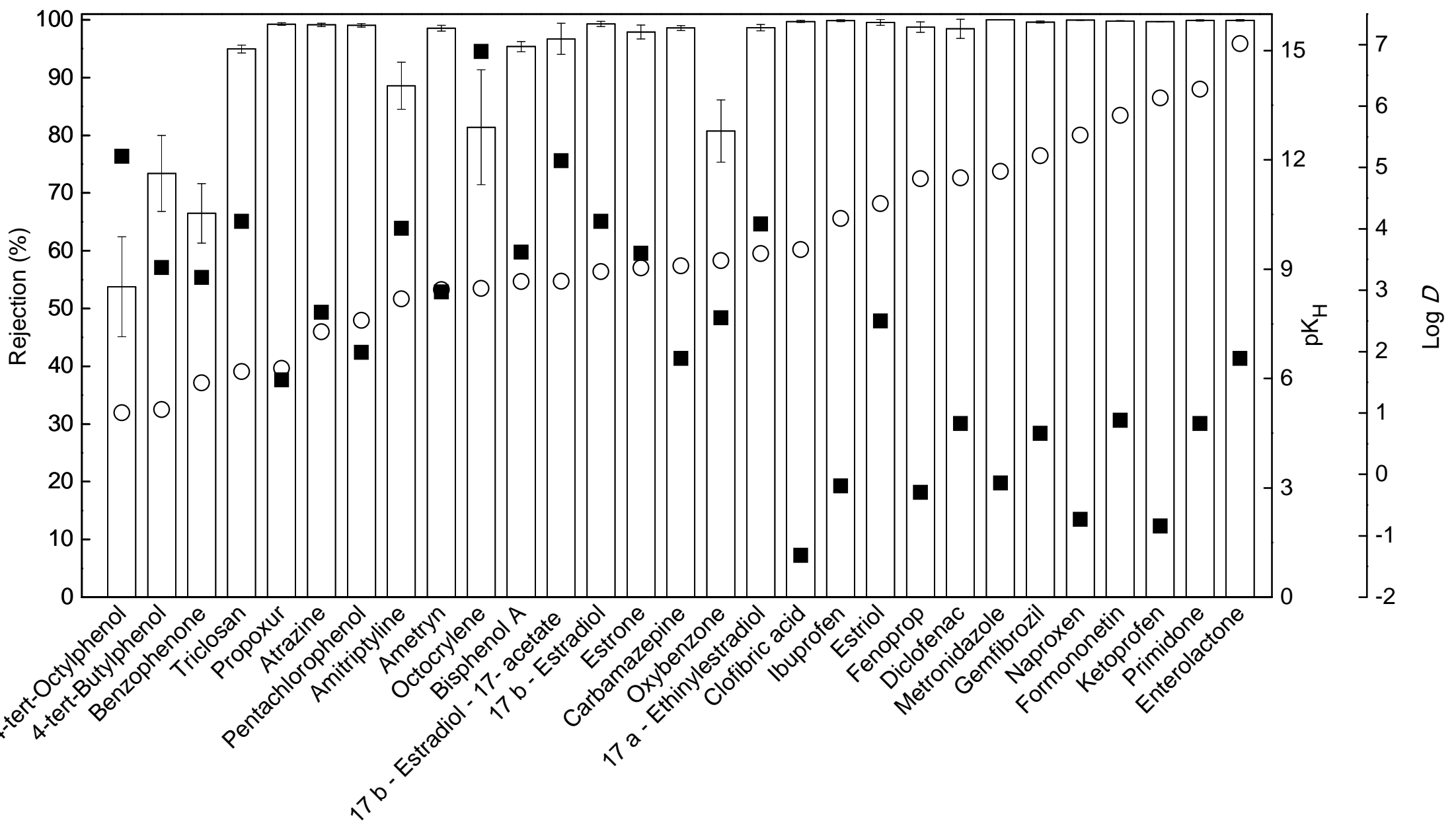

$2 \quad$ Figure 3 


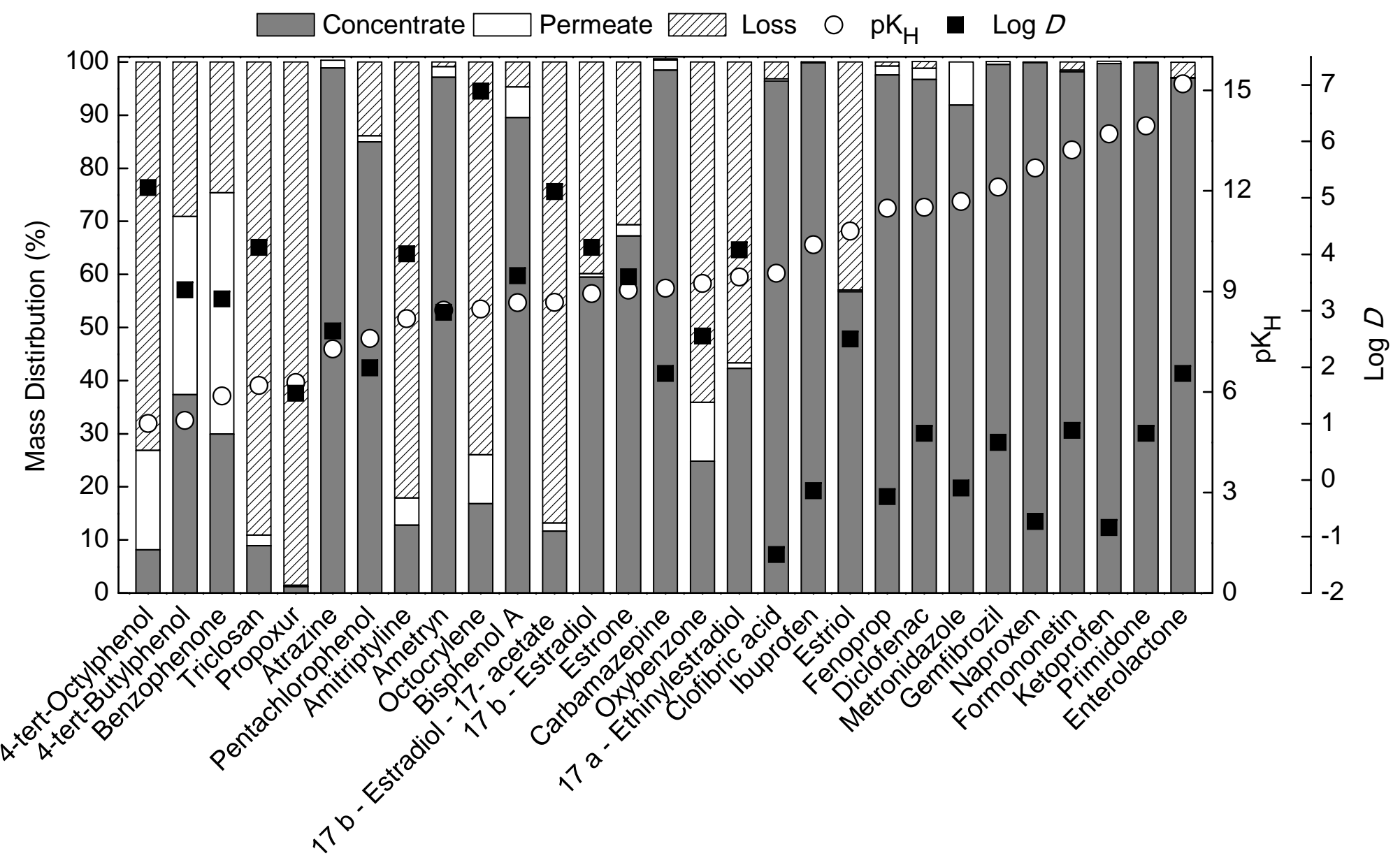

$2 \quad$ Figure 4 


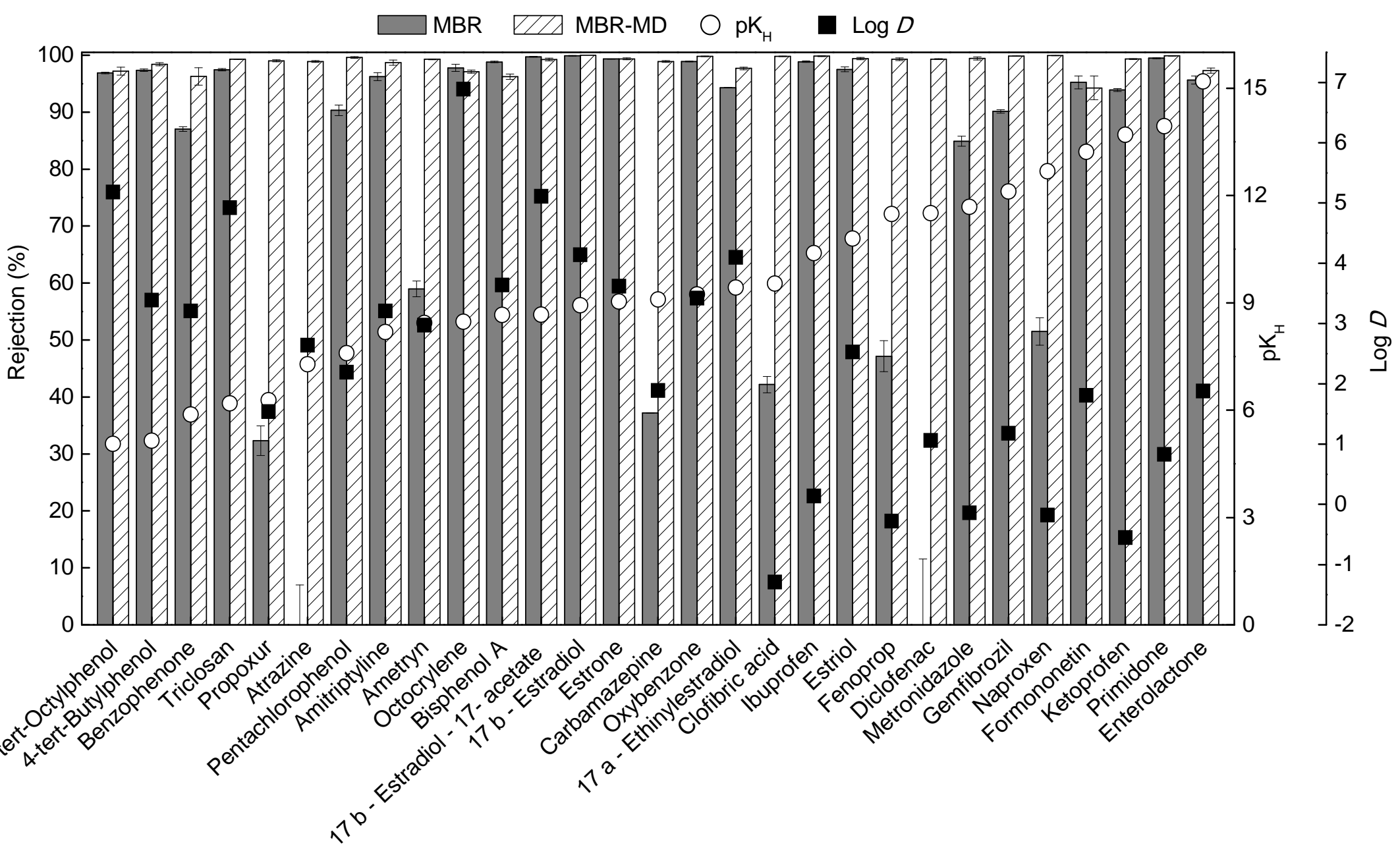

2 Figure 5 


\section{LIST OF TABLES}

2 Table 1: Physicochemical properties of the selected compounds (data from Scifinder Scholar).

\begin{tabular}{|c|c|c|c|c|c|c|}
\hline Compound & $\begin{array}{l}\text { Chemical } \\
\text { Formula }\end{array}$ & $\begin{array}{l}\text { Molecular Weight } \\
(\mathrm{g} / \mathrm{mol})\end{array}$ & $\begin{array}{c}\log D \text { at } \\
\text { pH } 9\end{array}$ & $\begin{array}{c}\text { Water Solubility at } \\
25^{\circ} \mathrm{C}(\mathrm{mg} / \mathrm{L})\end{array}$ & $\begin{array}{l}\text { Vapour Pressure } \\
\quad(\mathrm{mmHg})\end{array}$ & $\begin{array}{c}\mathrm{pK}_{\mathrm{H}} \text { at } \\
\mathrm{pH} 9\end{array}$ \\
\hline Enterolactone & $\mathrm{C}_{18} \mathrm{H}_{18} \mathrm{O}_{4}$ & 298.33 & 1.89 & 200 & $3.29 \times 10^{-13}$ & 15.19 \\
\hline Primidone & $\mathrm{C}_{12} \mathrm{H}_{14} \mathrm{~N}_{2} \mathrm{O}_{2}$ & 218.25 & 0.83 & 1,500 & $6.08 \times 10^{-11}$ & 13.93 \\
\hline Ketoprofen & $\mathrm{C}_{16} \mathrm{H}_{14} \mathrm{O}_{3}$ & 254.30 & -0.84 & 554,000 & $3.32 \times 10^{-8}$ & 13.70 \\
\hline Formononetin & $\mathrm{C}_{16} \mathrm{H}_{12} \mathrm{O}_{4}$ & 268.26 & 0.88 & 4800 & $8.17 \times 10^{-10}$ & 13.22 \\
\hline Naproxen & $\mathrm{C}_{14} \mathrm{H}_{14} \mathrm{O}_{3}$ & 230.30 & -0.73 & 435,000 & $3.01 \times 10^{-7}$ & 12.68 \\
\hline Gemfibrozil & $\mathrm{C}_{15} \mathrm{H}_{22} \mathrm{O}_{3}$ & 250.30 & 0.67 & 263,000 & $6.13 \times 10^{-7}$ & 12.11 \\
\hline Metronidazole & $\mathrm{C}_{6} \mathrm{H}_{9} \mathrm{~N}_{3} \mathrm{O}_{3}$ & 171.15 & -0.14 & 29,000 & $2.67 \times 10^{-7}$ & 11.68 \\
\hline Diclofenac & $\mathrm{C}_{14} \mathrm{H}_{11} \mathrm{Cl}_{2} \mathrm{NO}_{2}$ & 296.15 & 0.83 & 20,000 & $1.59 \times 10^{-7}$ & 11.51 \\
\hline Fenoprop & $\mathrm{C}_{9} \mathrm{H}_{7} \mathrm{Cl}_{3} \mathrm{O}_{3}$ & 269.51 & -0.29 & 230,000 & $2.13 \times 10^{-6}$ & 11.48 \\
\hline Estriol & $\mathrm{C}_{18} \mathrm{H}_{24} \mathrm{O}_{3}$ & 288.40 & 2.5 & 32 & $1.34 \times 10^{-9}$ & 10.80 \\
\hline Ibuprofen & $\mathrm{C}_{13} \mathrm{H}_{18} \mathrm{O}_{2}$ & 206.30 & -0.19 & 928,000 & $1.39 \times 10^{-4}$ & 10.39 \\
\hline Clofibric acid & $\mathrm{C}_{10} \mathrm{H}_{11} \mathrm{ClO}_{3}$ & 214.64 & -1.32 & 100,000 & $1.03 \times 10^{-4}$ & 9.54 \\
\hline $17 \alpha-$ Ethinylestradiol & $\mathrm{C}_{20} \mathrm{H}_{24} \mathrm{O}_{2}$ & 296.48 & 4.08 & 3.9 & $3.74 \times 10^{-9}$ & 9.43 \\
\hline Oxybenzone & $\mathrm{C}_{14} \mathrm{H}_{12} \mathrm{O}_{3}$ & 228.24 & 2.55 & 2700 & $5.26 \times 10^{-6}$ & 9.23 \\
\hline Carbamazepine & $\mathrm{C}_{15} \mathrm{H}_{12} \mathrm{~N}_{2} \mathrm{O}$ & 236.27 & 1.89 & 220 & $5.78 \times 10^{-7}$ & 9.09 \\
\hline Estrone & $\mathrm{C}_{18} \mathrm{H}_{22} \mathrm{O}_{2}$ & 270.36 & 3.6 & 5.9 & $1.54 \times 10^{-8}$ & 9.03 \\
\hline $17 \beta-$ Estradiol & $\mathrm{C}_{18} \mathrm{H}_{24} \mathrm{O}_{2}$ & 272.38 & 4.12 & 3 & $9.82 \times 10^{-9}$ & 8.93 \\
\hline $17 \beta$-Estrodiol- 17 - acetate & $\mathrm{C}_{20} \mathrm{H}_{26} \mathrm{O}_{3}$ & 314.42 & 5.11 & 1.9 & $9.88 \times 10^{-9}$ & 8.67 \\
\hline Bisphenol A & $\mathrm{C}_{15} \mathrm{H}_{16} \mathrm{O}_{2}$ & 228.29 & 3.62 & 73 & $5.34 \times 10^{-7}$ & 8.66 \\
\hline Octocrylene & $\mathrm{C}_{24} \mathrm{H}_{27} \mathrm{~N}$ & 361.48 & 6.89 & 0.36 & $2.56 \times 10^{-9}$ & 8.47 \\
\hline Ametryn & $\mathrm{C}_{9} \mathrm{H}_{17} \mathrm{~N}_{5} \mathrm{~S}$ & 227.33 & 2.97 & 140 & $1.72 \times 10^{-6}$ & 8.43 \\
\hline Amitriptyline & $\mathrm{C}_{20} \mathrm{H}_{23} \mathrm{~N}$ & 277.40 & 4.01 & 83 & $1.50 \times 10^{-6}$ & 8.18 \\
\hline Pentachlorophenol & $\mathrm{C}_{6} \mathrm{HCl}_{5} \mathrm{O}$ & 266.38 & 1.99 & 4800 & $3.49 \times 10^{-4}$ & 7.59 \\
\hline Atrazine & $\mathrm{C}_{8} \mathrm{H}_{14} \mathrm{ClN}_{5}$ & 215.68 & 2.64 & 69 & $1.27 \times 10^{-5}$ & 7.28 \\
\hline Propoxur & $\mathrm{C}_{11} \mathrm{H}_{15} \mathrm{NO}_{3}$ & 209.24 & 1.54 & 800 & $1.53 \times 10^{-3}$ & 6.28 \\
\hline Triclosan & $\mathrm{C}_{12} \mathrm{H}_{7} \mathrm{Cl}_{3} \mathrm{O}_{2}$ & 289.54 & 4.12 & 19 & $3.26 \times 10^{-5}$ & 6.18 \\
\hline Benzophenone & $\mathrm{C}_{13} \mathrm{H}_{10} \mathrm{O}$ & 182.22 & 3.21 & 150 & $8.23 \times 10^{-4}$ & 5.88 \\
\hline 4-tert-butyphenol & $\mathrm{C}_{10} \mathrm{H}_{14} \mathrm{O}$ & 150.22 & 3.37 & 1000 & 0.0361 & 5.15 \\
\hline 4-tert-octylphenol & $\mathrm{C}_{14} \mathrm{H}_{22} \mathrm{O}$ & 206.33 & 5.18 & 62 & $1.98 \times 10^{-3}$ & 5.06 \\
\hline
\end{tabular}

